\title{
Peptides and Exorphins in the Autism Spectrum
}

\author{
Dag Tveiten1, Adrian Finvold1, Marthe Andersson1, Karl L. Reichelt1,2* \\ ${ }^{1}$ Lab 1, Harbitzalle 3, Skøyen, Oslo, Norway \\ ${ }^{2}$ Medical Faculty, Oslo University, Oslo, Norway \\ Email: ${ }^{*}$ karlr@ulrik.uio.no
}

Received 9 April 2014; revised 18 May 2014; accepted 30 June 2014

Copyright (C) 2014 by authors and Scientific Research Publishing Inc.

This work is licensed under the Creative Commons Attribution International License (CC BY).

http://creativecommons.org/licenses/by/4.0/

cC) (7) Open Access

\begin{abstract}
Problem: Some researchers have not found the opioids in urine of autistic children. We have therefore looked at this problem again. Method: Mass spectrometry and fragmentation mass spectrometry (MS/MS) have been carried out on peaks from the HPLC that show co-chromatography with synthetic standards and peaks that are shared by different autistic children. Results: In quickly frozen urine we find the presence of exorphins, and can also demonstrate a rather fast break down at room temperature of these peptides in urine. Conclusion: Exorphins are present in urine in autistic children, but must be protected against break down and aggregation by fast freezing or acetic acid and adjusting declustering potential and collision potential during mass-spectroscopy. Specific antibody increases and the effect of removing precursor proteins from the diet reinforce this view.
\end{abstract}

\section{Keywords}

Autism, Behavior, Diet, Exorphins, Mass-Spectrometry, Peptides

\section{Introduction}

Previously the presence of exorphins such as gluten-morphins and casomorphins has been reported after fractionating urine from autistic children using HPLC [1]-[3]. Spiking with standard synthetic peptides and different elution gradients was used, and in some cases also antibody binding provided by Prof. Teschemacher, Giessen, Germany. Single ion mass spectroscopy also pointed to possible exorphins [4]. Furthermore opioid like physiological effects were reported and blocked by opioid antagonists. Thus increased dopaminergic activity due to inhibited uptake into synaptosomes, [5] [6], behavioral changes like hyperactivity followed by catatonia [6] [7],

${ }^{*}$ Corresponding author. 
Fos antigen induction in key nuclei of the brain [8], and analgesic effects were also observed [6].

However, several groups did not find these peptides [9] [10] using highly sophisticated techniques, much to our consternation. A Russian group serum levels of casomorphin 1-7 (bovine), which were negatively correlated to psychomotor development in children with psychomotoric problems [11].

\section{Methods}

Patients between ages 2 and $18(n=335)$ were diagnosed after DSM III and IV. The urines were obtained from Italy by Association Planet Autism; from Serbia by Dr. Selakovic, Beograd, Serbia, from Slovenia by D. Patterson, MD, of Runaway Bay, Queensland, Australia. Controls are Norwegian children provided by education specialist M. Nodland, Stavanger. The children clearly belonged to the Autism spectrum (CPDD). The age range was 3 - 12 years for controls, for patients 2 - 13 years.

\section{Urine Analysis}

First morning urine was quickly frozen at $-15^{\circ} \mathrm{C}$. We usually ask for $10 \mathrm{ml}$ to ensure that the freezing is as fast as possible. In the laboratory the urines were thawed overnight in the cold room $\left(4^{\circ} \mathrm{C}\right)$ and $\mathrm{pH}$ was measured. $800 \mu \mathrm{L}$ was filtered through Spin X centrifuge filters from Costar at $3000 \mathrm{xg}$ for $20 \mathrm{~min}$ at 20 degrees. (This was necessary to prevent blocking the filters unfortunately). The samples where then kept frozen at $-15^{\circ} \mathrm{C}$ until analysed. The Spin X tubes were made of polyethylene and the filters $0.22 \mu \mathrm{M}$ were made of Cellulose acetate.

Creatinine was kindly measured by the Dept of Clinical Biochemistry at Oslo Univ. Hosp., Rikshospitalet. HPLC was run on aliquots equivalent to 250 nmoles creatinine applied to C-18 reverse columns (Vydac C-18 peptide/protein columns Catalogue no 218TP54 from the USA). The columns were eluted with TFA (Trifluoroacetic acid) $10 \mathrm{mM}$ and acetonitril gradients [12]. Peptide bonds were read at $215 \mathrm{~nm}$, aromatic groups at 280 and indolyl groups at $315 \mathrm{~nm}$. Rate of elution was $1 \mathrm{ml} / \mathrm{min}$. at $30^{\circ} \mathrm{C}$.

The gradient was started after $15 \mathrm{~min}$. isocratic run with the TFA buffer.

To determine which peaks to analyse, urines with reasonably similar elution patterns and diagnoses were combined five or ten at the time and re-analysed collectively as described. Peaks common to all then stay the same or increase, while individual peaks are diluted out (A technique learned from P Shattock o.b.e. at the time he worked at Sunderland Univ. UK). All samples were thoroughly stirred by electric shaker for $1 / 2 \mathrm{~min}$. before application.

To demonstrate that the peaks eluting after hippuric acids are mostly peptides or peptoids, the eluted material was hydrolysed in $6 \mathrm{M}$ HCL in closed tubes at 115 degrees $\mathrm{C}$ overnight and the $\mathrm{HCl}$ removed in vacuum over $\mathrm{P}_{2} \mathrm{O}_{5}$ and $\mathrm{KOH}$ pellets. The residue was analyzed on an amino acid analyser using ninhydrin technique and compared to not hydrolysed equal aliquot.

\section{Mass Spectrometry}

Freeze dried material from collective or individual HPLC runs were re-dissolved in methanol/water (1/1 by volume) and made $10 \mathrm{mM}$ to formic acid. The sample was dissolved in $300 \mu \mathrm{L}$ buffer and applied to a P-sciex 2000 quadropole mass spectrometer by micro-pump and direct inlet. Dominant ion peaks or peaks appearing where opioid standards elute, were subjected to fragmentation (MS/MS). Each peak had to have its Declustering potential and Collision potential adjusted to appropriate levels so that we retained visible amounts of the "mother" ion. This was done by ratching up or down as required in this paper we demonstrate the presence and increase of peptides in autism and the nature of some as exorphins. We also refer to the effect of diet and to the increase in anti-food antibodies as support for the probability of the outlined findings.

\section{Ethics}

The procedure does no harm to the patients and we all have to pass our urine anyway. The research is covered by permission from the local ethical committee S-06270a.

\section{Results}

In Figure 1 the normal and in Figure 2 a typical early onset autism pattern is seen, although this varies consid- 


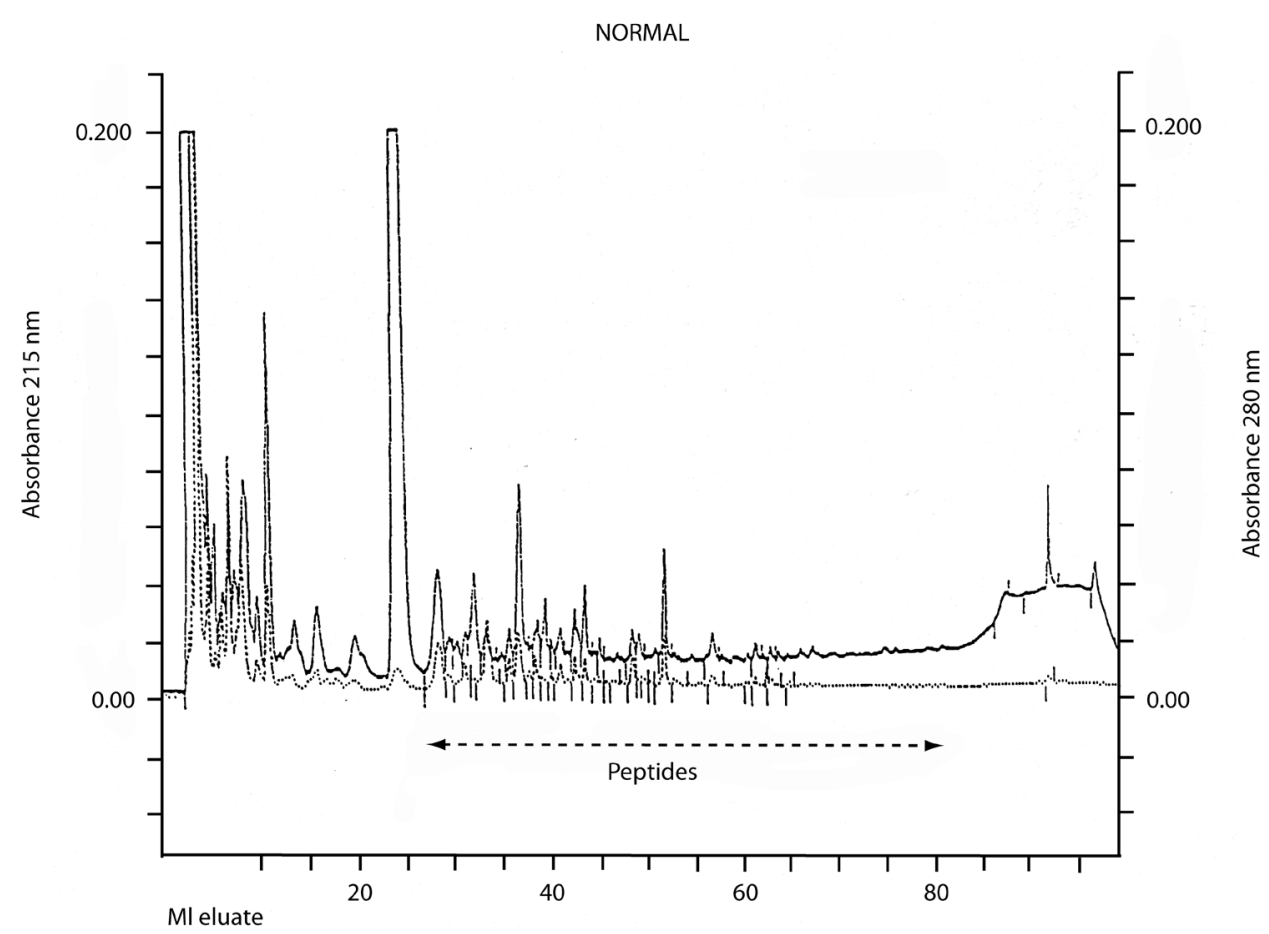

Figure 1. Shows the HPLC elution pattern of a normal child, Hippuric acid elutes with a big peak at $27 \mathrm{ml}$. Urine equivalent to 250 nanomoles creatinine was applied to C-18 reverse phase column.

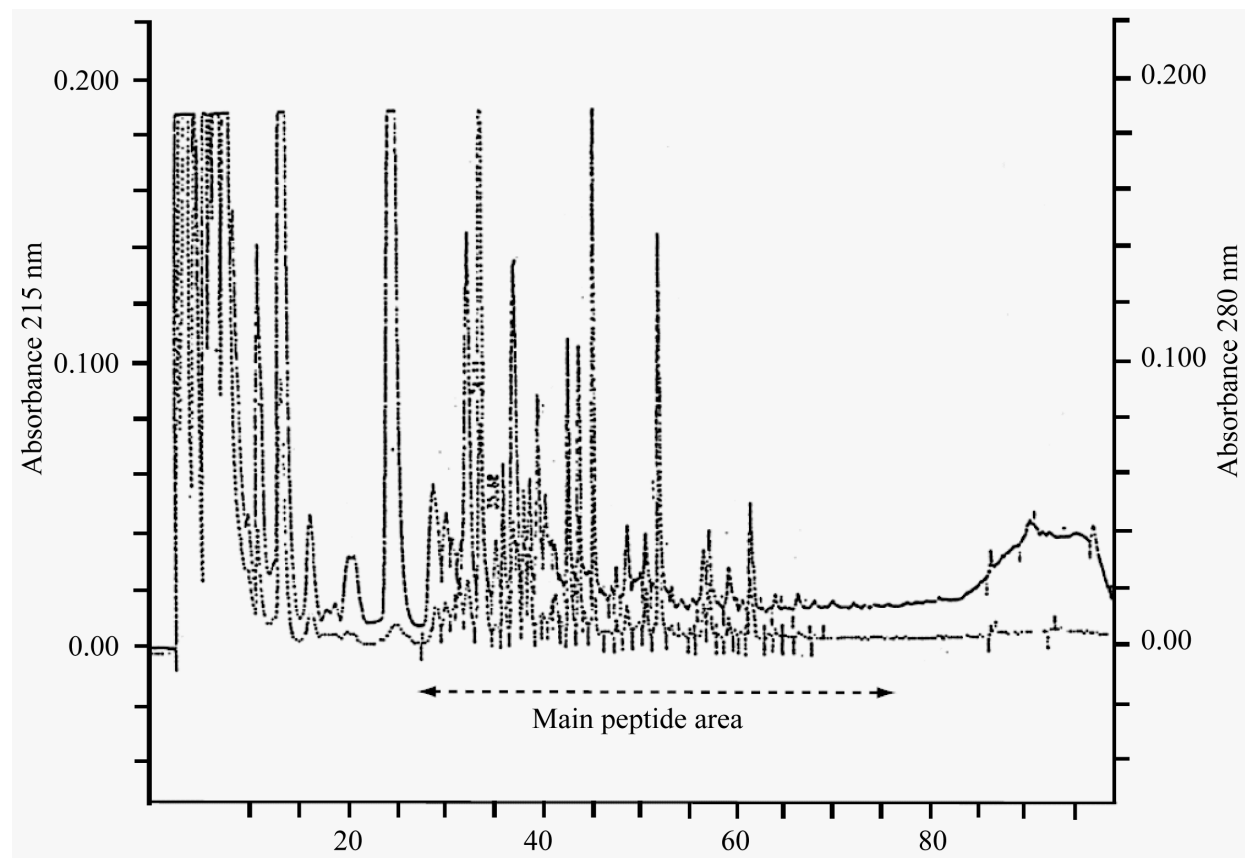

Figure 2. The HPLC pattern of an infantile autistic child 6 years old with early onset.

erably. If not frozen and kept cool there is a substantial reduction in peptides seen after hippuric acid. To demonstrate that the peaks after hippuric acid were peptides, amino acid analysis before and after hydrolysis was performed. Figure 3, illustrates this for a non-opioid peptide.

To avoid National peculiarities from for instance diet, total level of peptides measured as area under the 215 nano-meter curve can be seen (Table 1). 


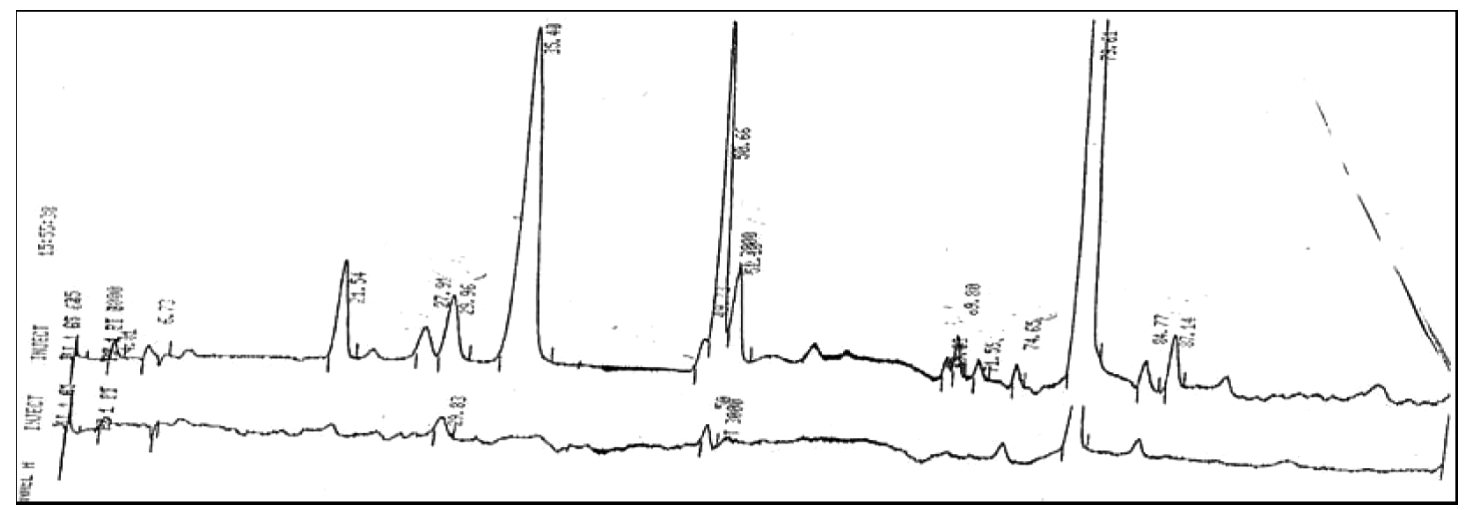

Figure 3. Bottom trace before and upper trace after hydrolysis analysed on an amino acid analyzer of a non opioid peptide peak from the HPLC.

Table 1. The sum of UV 215nM areas after hippuric acid in urine from different countries.

\begin{tabular}{ccccc}
\hline & Italy & Serbia & Slovenia & Controls \\
\hline Mean & 409 & 584 & 564 & 289 \\
SD & 307 & 504 & 523 & 84 \\
$\mathrm{~N}$ & 145 & 139 & 51 & 181 \\
$95 \% \mathrm{CI}$ & 343 & 500 & 416 & 277 \\
& 463 & 687 & $\mathrm{~T} 11$ & 302 \\
\hline
\end{tabular}

Clearly increased peptide levels over controls in the autism spectrum. The area under the 215 nanometer peaks in arbitrary units. The extreme SD is due to some very high levels og peptide peaks especially in late onset regressive autism. The autism spectrum children are different from controls as seen in table.

In Figure 4 and Figure 5 a normal urine is spiked with Beta casomorphin 1-4 (bovine). Left at room temperature this exorphins shows a rapid break down (Figure 5). This must apparently be caused by a peptidasewhich passes through ultra-filtration pores with cut off for substances larger than 3K Daltons. However if needle shaped larger molecules can be upended and pass through.

In Figure 6 the presence of glumorphine A5 (G-Y-Y-P-T) is demonstrated by fragmentation mass spectrometry (MS/MS) and comparing this with synthetic standard. They are clearly the same compound.

In Figure 7 Bovine $\beta$-casomorphine 1-7 (Y-P-F-P-G-P-I) is fragmented and again compared to synthetic standard, Also these two compounds are the same. It should be noted that not all urines from autistic children contain the same opioids, and why this is so, we do not know. Some contain several and some only one. Very few are negative. The same procedure was followed for bovine or human casomorphin 1-3 (Figure 8). Again the fragmentation pattern is the same.

Also Bovine $\beta$-casomorphine 1-4 was found as seen in Figure 9.

Late onset and more regressive autism have statistically increased peptide levels compared to early onset autism. Late onset $1526 \pm 926$ units measured as area below the UV $215 \mathrm{~nm}$ curve $(\mathrm{n}=25)$, neonatal onset $570 \pm$ $198(\mathrm{n}=45)$ and $\mathrm{p}=0.0001$ Mann Whitney U-test, two-tailed. The level for Scandinavian children has been published previously [6] [11]. A correlation of urine peptide level to degree of autism has been published [13]. When we use only HPLC technology, high functioning autistic children overlap with controls to a degree which make diagnosis difficult [14].

To ensure safer diagnoses a mass spectrometric fragmentation technique is being developed at the Biomedical Laboratory using reporter ions (In preparation).

\section{Discussion}

Freezing as soon and possible or adding concentrated acetic acid (1\% by volume) clearly preserved exorphins 


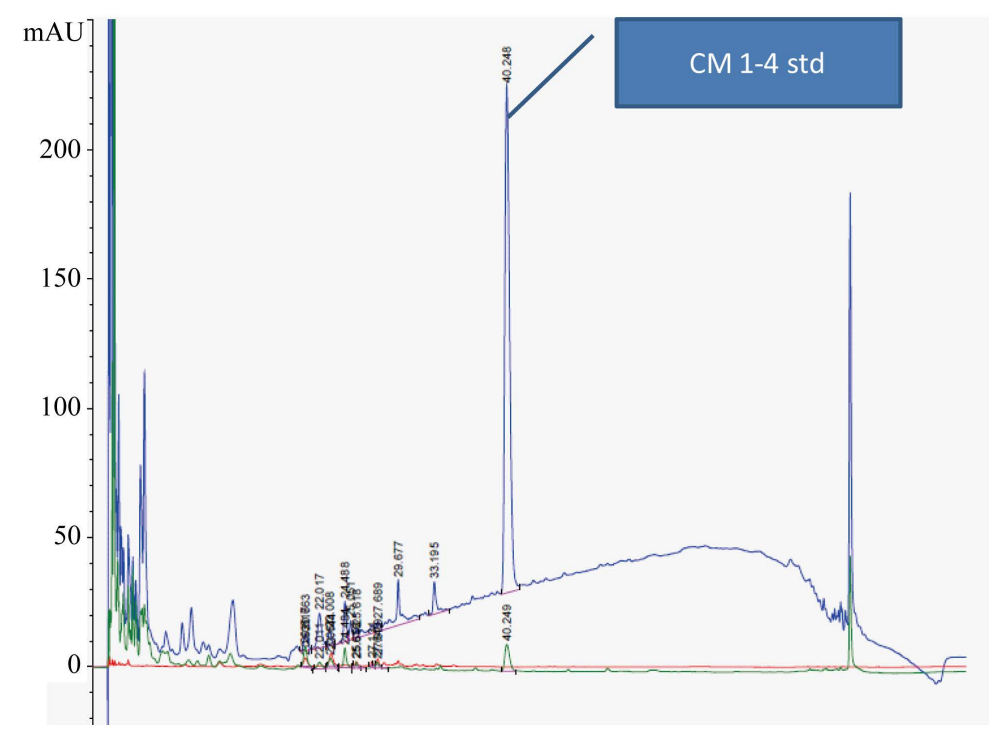

Figure 4. A normal urine spiked wirh Bovine $\beta$-casomorphinw 1-4 (Bovine).

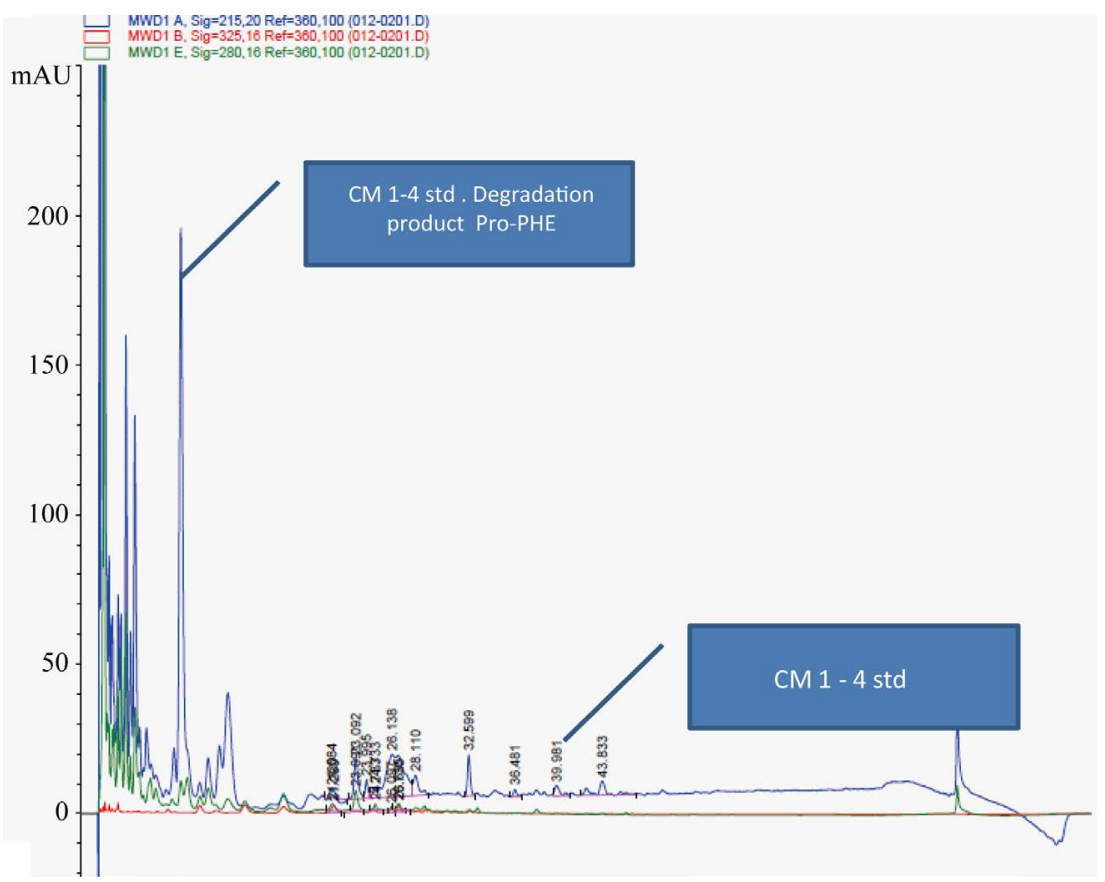

Figure 5. Spiked urine after 12 hours. The same spiked urine as in Figure 3 after being exposed to room temperature for more than 12 hours. The peptide is almost completely broken down to Pro. Phe The urine had been ultrafiltrated through filters with a $3 \mathrm{~K}$ cut off.

and can be found on HPLC and fragmentation mass spectroscopy. Why different autistic children have different opioids present we do not understand. Some of the shorter opioids could be break down products from larger precursors. The opioids are bioactive. Thus opioidreceptor binding [12] and analgesia studied by the tail flick test [5] have been found. Furthermore, IV injection caused hyperactivity and later catatonia [3] [5] and Fos antigen activation in key nuclei of rat brain [8] such as the nucleus accumbens. All these behavioral changes were blocked by naloxone. The opioid peptide also caused decreased uptake of dopamine in striatal synaptosomes and showed in vivo dopaminergic hyperactivity using the Ungerstedt model [5]. Also linking autism to dietary proteins was the discovery of antibodies against gluten, gliadin and casein increased in autistic children [15]-[19]. A Russian group [11] found that casomorphin in the blood was inversely related to psychomotor development in 

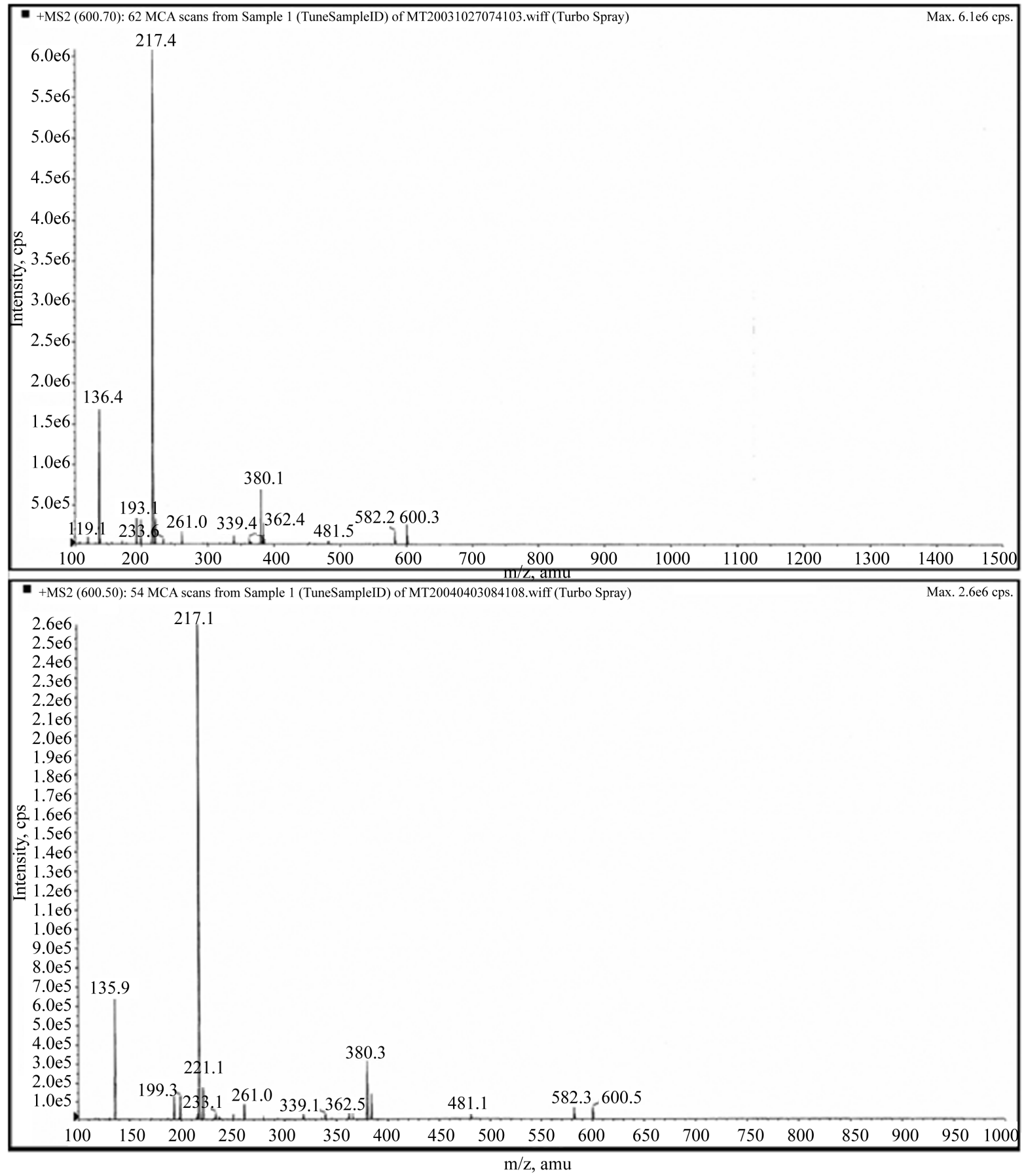

Figure 6. Demonstration of glumorphin A-5 (G-Y-Y-P-T) by MS/MS (fragmentation). Top trace is synthetic standard, and bottom trace Glumorphin A5 isolated from regressive autistic children's urine. Declustering potential was set at 20 and collision energy at 30 . The $\mathrm{X}$ axis has been extended in the bottom trace to secure against hidden ion peaks.

infants. Casomorphins have furthermore, been shown to abrogate separation distress call and reaction in newly hatched chickens [20] and also causing social isolation in kittens, pups. and newly hatched chicken.

\section{A Gut to Brain Axis Exists}

Peptides are formed in the gut from food proteins [21] [22] and we all take up peptides from the gut [22] [23]. If 


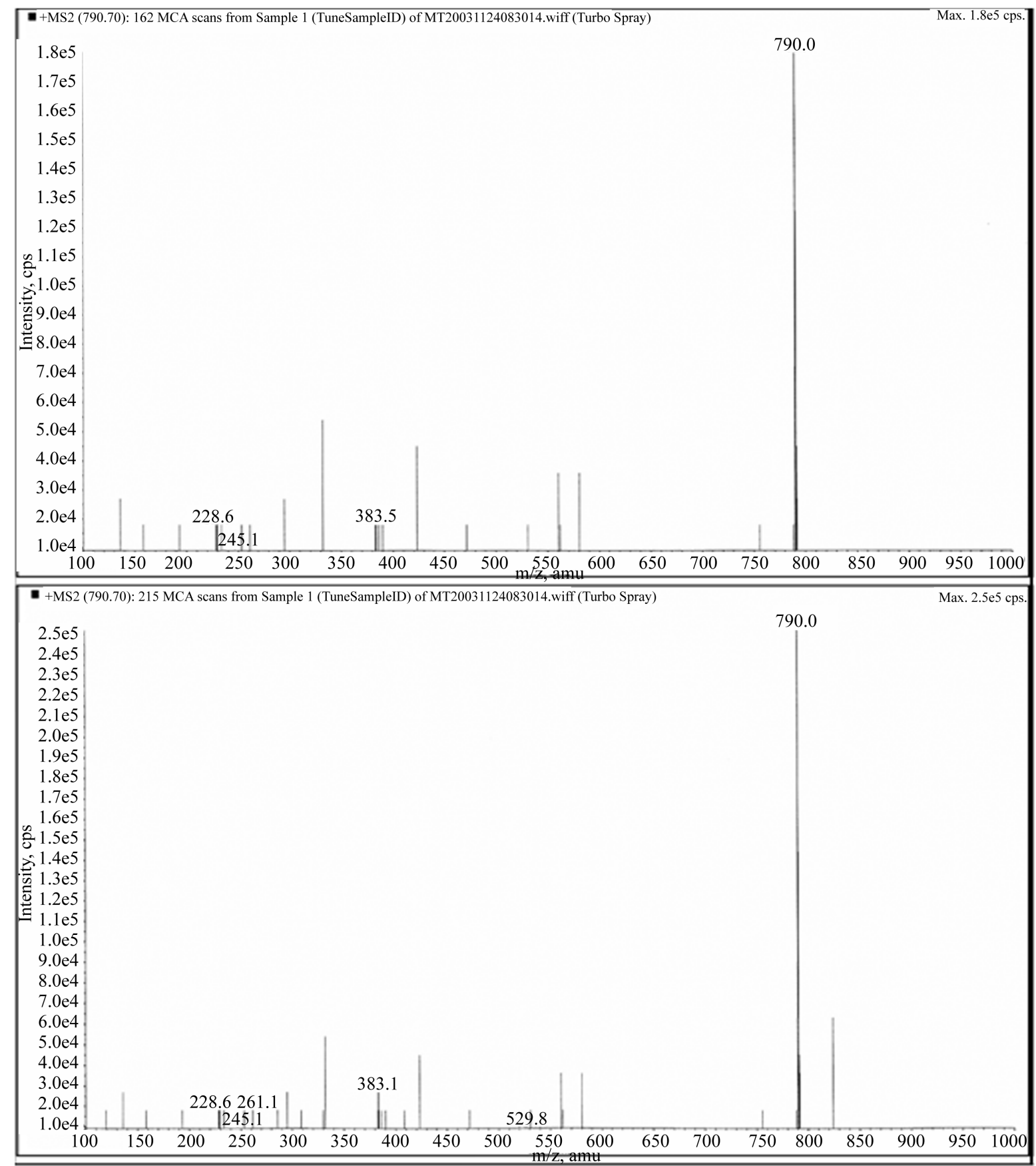

Figure 7. Fragmentation of Bovine casomorphin 1-7. Bovine $\beta$-casomorphin 1-7 (Y-P-F-P-G-P-I). Upper trace is synthetic standard and lower trace the HPLC from where standards elute. The peak appearing after the intact casomoprhine 1-7 ion could be removed by increasing the declustering potential. It is shown here to illustrate the strong propensity for peptides to form aggregates and adducts. Declustering here is 20 and collision potential is 70 .

peptidases are inhibited or lacking, this uptake is increased [24] [25]. Opioid peptides also get across the bloodbrain barrier [26] [27].

Antibodies against food proteins are increased in autism and point to increased uptake of protein. Humans take up intact protein [23] [28] and intact enzymes [29]. These proteins can be recovered from mother's milk [30] [31]. Thus Botulinum toxin is a peptidase that is taken up from the gut, crosses the blood-brain barrier and the presynaptic membrane and splits one peptide bond in SNAP-25 with fatal results [32]. Some antibodies, for 


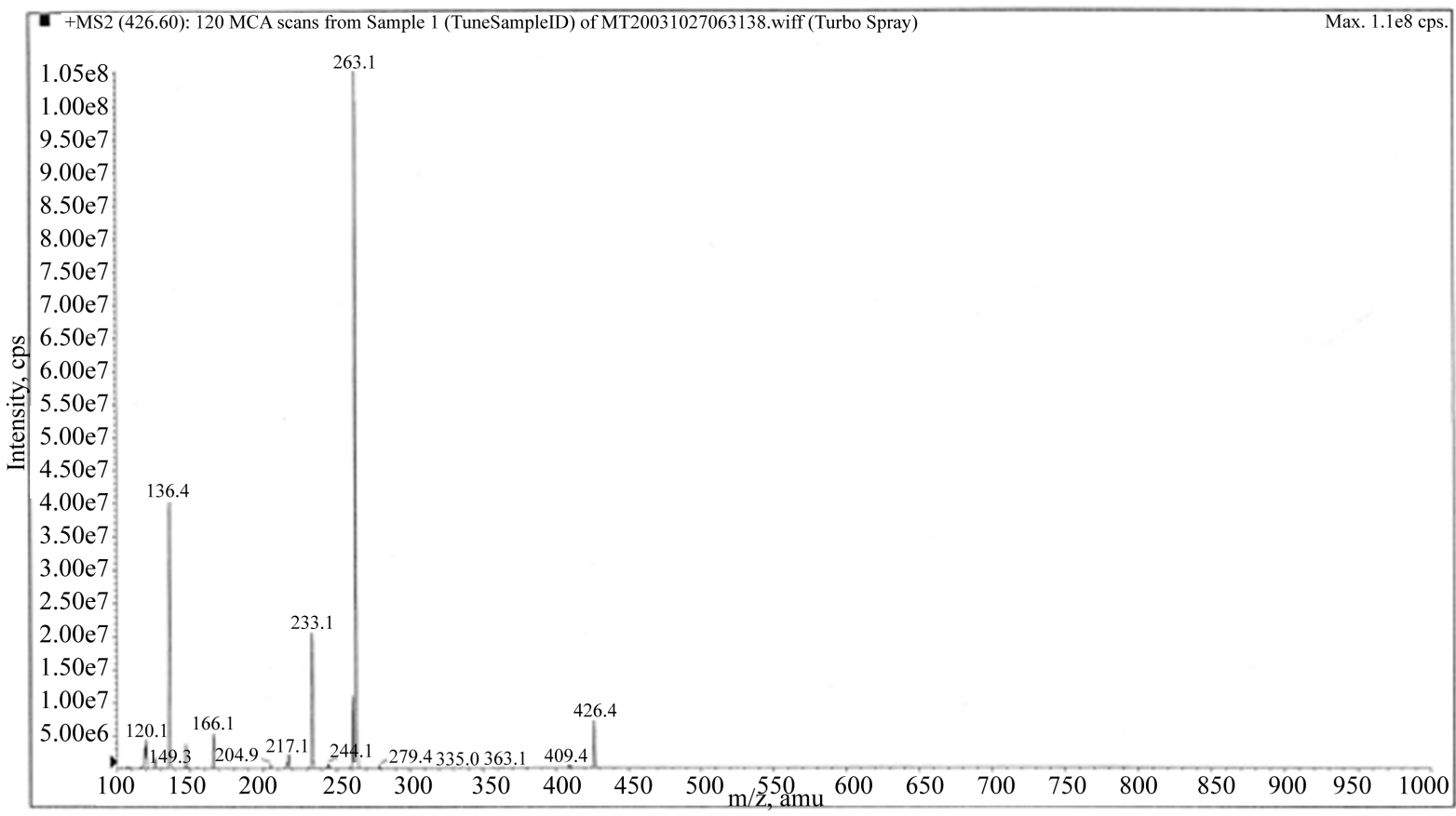

(a)

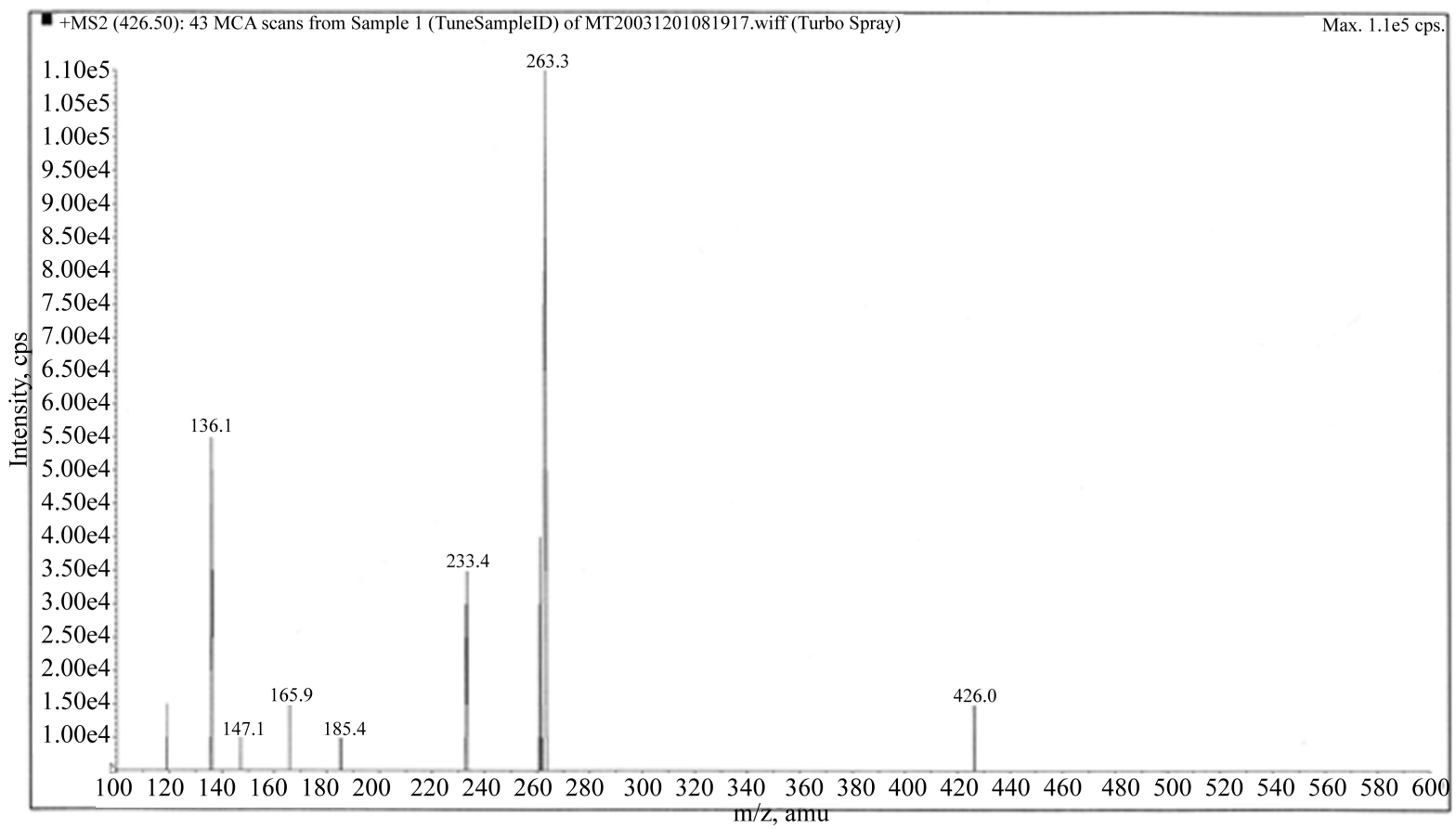

(b)

Figure 8. Casomorphin 1-3 (Y-P-F). Top trace synthetic and bottom trace from autistic child. The X axis has been extended not to overlook other fragments. Declustering potential 20 and collision potential sat at 30.

instance against gliadin [33], have direct effects on Purkinje cells of the cerebellum. Considerable intestinal problems are found in autistic spectrum disorders [34]-[36] which would result in increased uptake. Casein and gluten can also release inflammatory cytokines in autism [37] and such cytokines increase permeability of endothelial barriers [38]. In autism increased gut permeability has been established [39] [40] and, therefore, the 


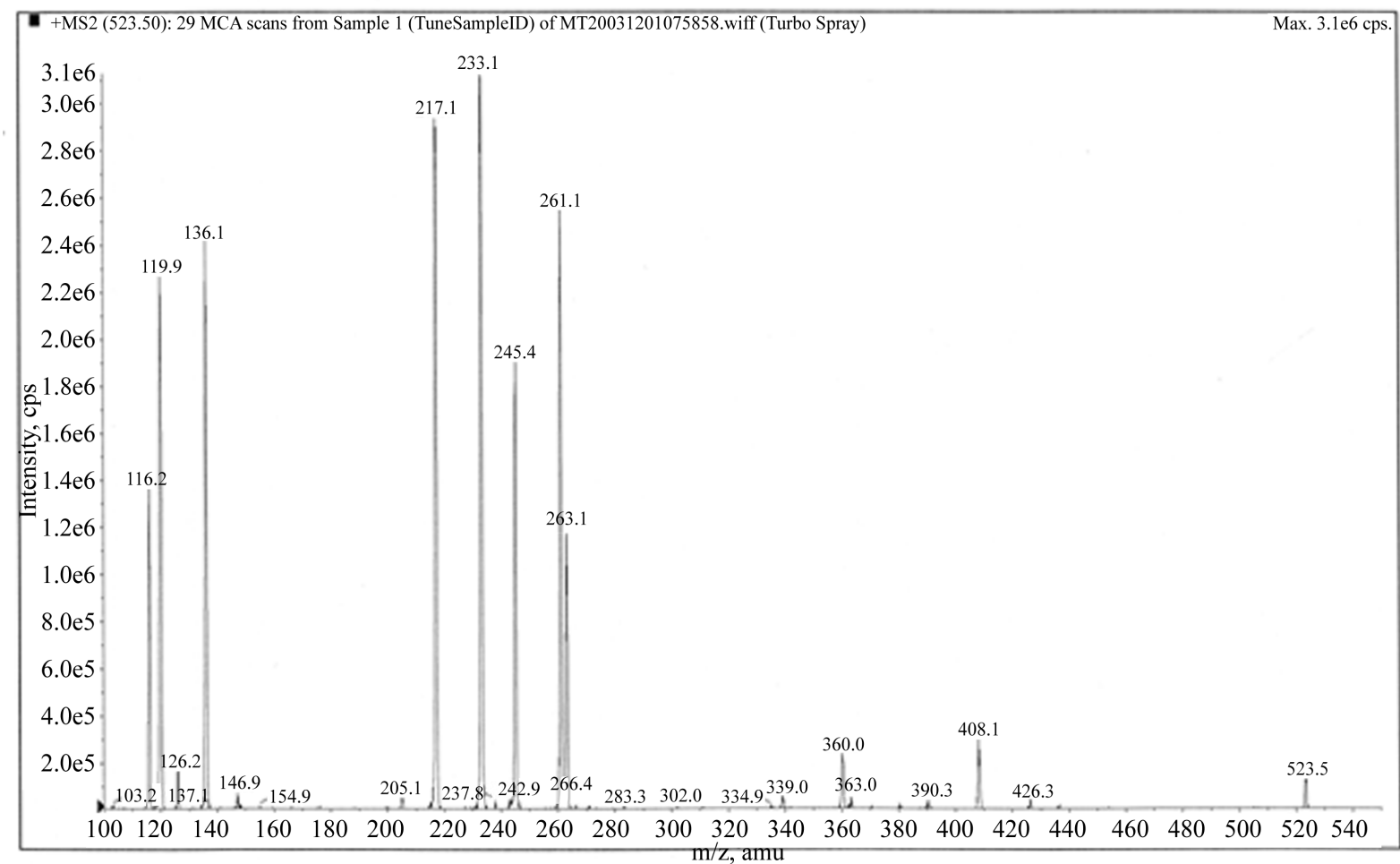

(a)

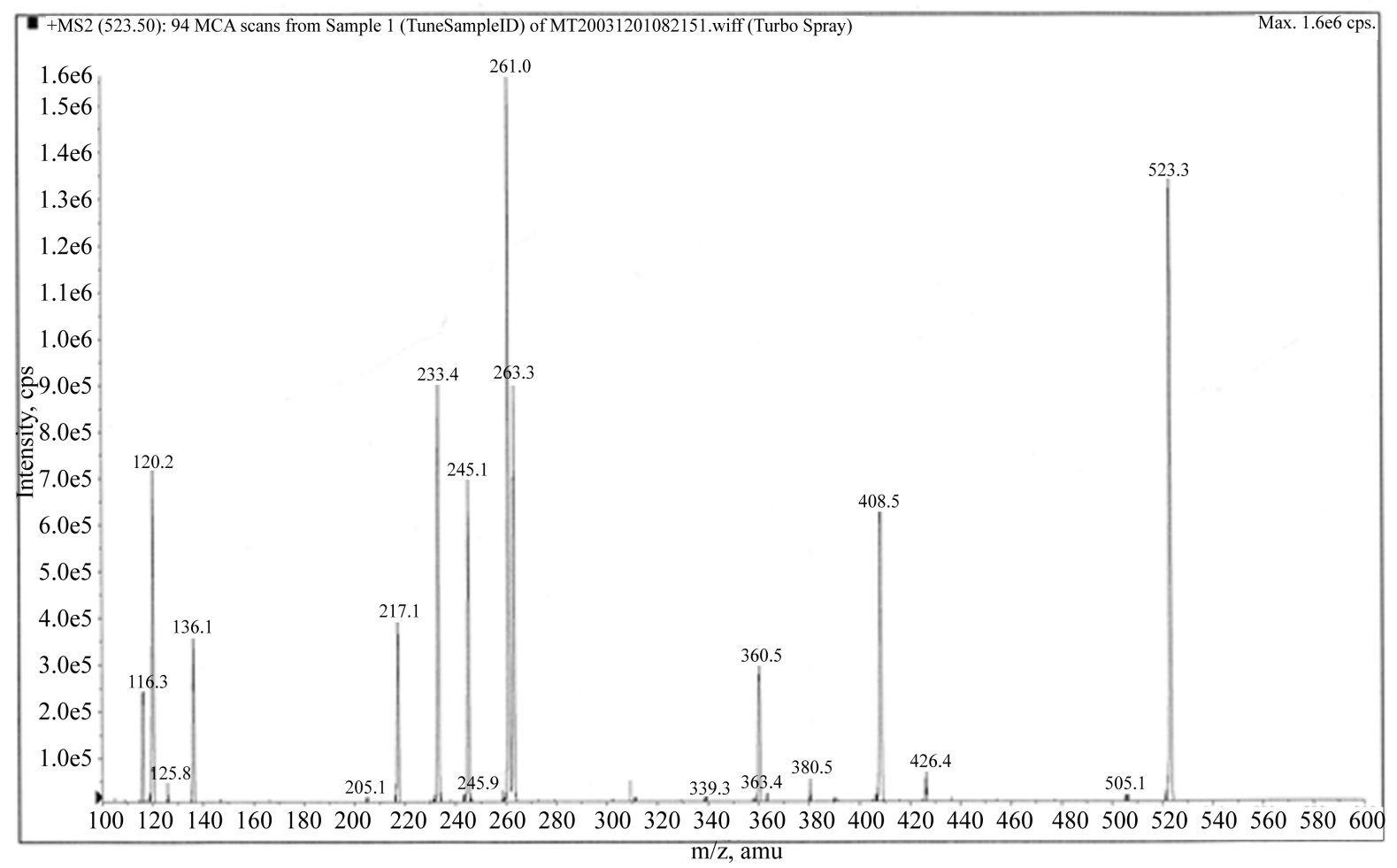

(b)

Figure 9. Top trace is synthethic Bovine casomorphin 1-4 (Y-P-F-P) from Bachem and bottom trace from an autistic child. The $\mathrm{X}$ axis has been expanded to avoid overlooking peaks (the bottom trace). Declusering at 20 and collision potential at 30 . In the bottom trace the collision energy was 20 units. 
Table 2. Open study of diet intervention at one and 3 years.

\begin{tabular}{|c|c|c|c|c|c|}
\hline Test & Initial & 1 year change & 3 year change & $\mathrm{N}$ & $P$ value \\
\hline C-Raven & $6.8 \pm 2.8$ & $+8.6 \pm 2.8$ & $+8.6 \pm 3.2$ & 12 & 0.005 \\
\hline ITPA & $25.7 \pm 5.5$ & $+2.7 \pm 2.5$ & $+6.1 \pm 2.8$ & 10 & 0.005 \\
\hline \multicolumn{6}{|l|}{ DIPAB } \\
\hline Social isolation & $8.5 \pm 3.3$ & $-6.1 \pm 2.7$ & & 14 & 0.005 \\
\hline Bizarre Traits & $5.3 \pm 2.2$ & $-5.3 \pm 1.22$ & & 14 & $<0.004$ \\
\hline
\end{tabular}

ITPA is Illinois Test of Psycholinguistic ability. A change of 0.5 units for this age adjusted test is significant. DIPAB is DIPAB: Diagnosis of Psychotic Behavior in Children: Compiled by Dr. D. Haracopus, Denmark). Mann Whiteney U test, two tailed used thoughout).

Table 3. Single blind pairwise randomly assigned autistic children and the one year effect of gluten and casein free diet (Knivsberg et al. 2002).

\begin{tabular}{|c|c|c|c|c|c|}
\hline $\begin{array}{c}\text { Tested for } \\
\text { Autistic symptoms }\end{array}$ & Before & After & $\begin{array}{l}\text { Significance } \\
\text { Diet to control }\end{array}$ & $\mathrm{N}$ & $\begin{array}{l}\text { Within group } \\
\text { significance }\end{array}$ \\
\hline Diet group & $12.5 \pm 2.2$ & $5.6 \pm 2.4$ & & 10 & 0.005 \\
\hline Controls & $11.5 \pm 3.9$ & $11.2 \pm 5$ & 0.001 & & 0.798 \\
\hline Aloofness & $7.6 \pm 1.7$ & $3.0 \pm 1.4$ & & 10 & 0.005 \\
\hline Controls & $7.1 \pm 2.8$ & $3.0 \pm 1.4$ & 0.003 & 10 & 0.337 \\
\hline $\begin{array}{l}\text { Communicative skills, } \\
\text { social skills }\end{array}$ & $3.9 \pm 0.9$ & $6.2 \pm 1.2$ & & 10 & 0.007 \\
\hline Controls & $4.3 \pm 1.3$ & $4.5 \pm 1.6$ & 0.004 & 10 & 0.623 \\
\hline Strange behaviour & $4.9 \pm 1.5$ & $2.6 \pm 1.7$ & & 10 & 0.07 \\
\hline Controls & $4.5 \pm 2.6$ & $4.8 \pm 2.6$ & 0.004 & 10 & 0.58 \\
\hline
\end{tabular}

Shows that similar changes to the open study are found. and that changes also occur with other treatments (No other changes were made than diet in the experimental group) Mann Whitney U test two tailed was used. For details and tests used see the original paper (Knivsberg et al. 2002).

prerequisite conditions for the postulated mechanism are present.

Additional indication that gluten and casein are important in the pathogenesis of autism follows from the effect of removing these precursors from the diet. This has been done and in quite a number of studies [3] [15] [41]-[51]. The length of the intervention is critical and short term trials such as 14 days are quite inadequate. Double blind dietary studies are very demanding, but single blind pairwise matched and randomly assigned studies [50], as well as testing over 3 years to counter act placebo effects [51], are very promising in spite of small numbers. However the statistical change is impressive, and indicates that dietary intervention is effective. In Table 2 we summarize the data from an open 4-year follow up and in Table 3 the results are shown of matched randomly assigned children with autism. Note that in the 3-year study children that quit the GF/CF diet regressed [12]. The numbers are small, but since diagnosis is symptomatic and not aetiological, pairwise matched randomly assigned studies are much more secure because this increases the probability of comparing similar patients.

A pairwise amd randomly assigned study [50] likewise find highly significant changes after one year on GF/CF diet. Given the heterogeneity of the autistic spectrum, with probably different aetiologies, this is probably a safer procedure than double blind which presupposes identical aetiologies.

The apparent increase in frequency of this disorder over the last decades may probably be due to mercury (Hg) found increased in autistic spectrum disorders in a series of investigations [52]-[54]. Hg is a severe enzyme poison and very toxic to nervous tissue, and binds almost irreversibly to SH groups on enzymes.

Overloading normal persons with gluten (Gliadin and glutenin) for 3 days gave measurable peak for glumorphin B5, which was spiked with synthetic B5 [55] and determines to 4 decimal places by mass spectroscopy.

\section{References}

[1] Reichelt, K.L., Knivsberg, A.M., Lind, G. and Nødland, M. (1991) Probable Etiology and Possible Treatment of Childhood Autism. Brain Dysfunction, 4, 308-319.

[2] Shattock, P., Kennedy, A., Rowell, F. and Berney, T. (1990) Role of Neuropeptides in Autism and Their Relationship 
with Classical Neurotransmitters. Brain Dysfunction, 3, 328-345.

[3] Cade, R.J., Privette, R.M., Fregly, M., Rowland, N., Sun, Z., Zele, V., et al. (2000) Autism and Schizophrenia: Intestinal Disorders. Nutritional Neuroscience, 3, 57-72.

[4] Shanahan, M.R., Venturini, A.J., Daiss, J.L. and Friedman, A.E. (2000) Peptide Diagnostic Markers for Human Disorders. European Patent Application, EP 0969015 A2: 1-44.

[5] Hole, K., Bergslien, A.A., Jørgensen, H., Berge, O.G., Reichelt, K.L. and Trygstad, O.E. (1979) A Peptide Containing Fraction from Schizophrenia Which Stimulates Opiate Receptors and Inhibits Dopamine Uptake. Neuroscience, 4, 1139-1147. http://dx.doi.org/10.1016/0306-4522(79)90062-9

[6] Reichelt, K.L., Hole, K., Hamberger, A., Sælid, G., Edminson, P.D., Braestrup, C.B., et al. (1981) Biologically Active Peptide-Containing Fractions in Schizophrenia and Childhood Autism. Advances in Biochemical Psychopharmacology, 28, 627-698.

[7] Sun, Z. and Cade, J.R. (1999) A Peptide Found in Schizophrenia and Autism Causes Behavioural Changes in Rats. Autism, 3, 85-95. http://dx.doi.org/10.1177/1362361399003001007

[8] Sun, Z., Cade, R.J., Fregly, M.J. and Privette, R.M. (1999) Beta-Casomorphine Induces Fos-Like Immunoreactivity in Discrete Brain Regions Relevant to Schizophrenia and Autism. Autism, 3, 67-83. http://dx.doi.org/10.1177/1362361399003001006

[9] Dettmer, K., Hanna, D., Whetstone, P., Hansen, R. and Hammock, B.D. Autism and Uinary Exogenous Neuropeptides; Developing an on Line SpE-HPLC Modem Mass Spectroscopy Method to Test the Opioid Excess Theory. Analytical and Bioanalytical Chemistry, 3007, 1643-1651

[10] Cass, H., Gringras, P., March, E., McKendrick, I., O’Harwe, A.E., Owen, I. and Pollinc, C. (2008) Absence of Urinary Opioid Peptides in Children with Autism. Archives of Disease Childhood, 93, 745-750.

[11] Kost, N.V., Sokolov, O.Y., Kurasova, O.B., Dimitriev, A.D.,Tarakanova, J.N., Gabaeva, M.V., et al. (2009) Beta-Casomorphin-7 in Infants on Different Type of Feeding and Different Levels of Psychomotor Development. Peptides, 30, 854-860. http://dx.doi.org/10.1016/j.peptides.2009.06.025

[12] Reichelt, K.L. and Knivsberg, A.M. (2003) Can the Pathophysiology of Autism be Explained by the Nature of the Discovered Urine Peptides? Nutritional Neuroscience, 6, 19-28. http://dx.doi.org/10.1080/1028415021000042839

[13] Sacco, R., Curatolo, P., Manzi, B., Militerni, R., Bravaccio, C., Froll, A., et al. (2010) Principal Pathogenetic Components and Biological Endophenotypes in Autism Spectrum Disorders. Autism Research, 3, 237-252. http://dx.doi.org/10.1002/aur.151

[14] Sponheim, E., Myhre, A.M., Reichelt, K.L. and Aasen, O.C. (2006) Peptidmønstre i Urin Hos Barn Med Mildere Former for Autisme. Tidsskr Nor Laegeforen, 126, 1475-1477.

[15] Reichelt, K.L., Ekrem, J. and Scott, H. (1990) Gluten, Milk Proteins and Autism: Dietary Intervention Effects on Behavior and Peptide Secretion. Journal of Applied Nutrition, 42, 1-11.

[16] Kawashti, M.I., Amin, O.H. and Rowely, N.G. (2008) Possible Immunological Disorders in Autism. Concomittant Autoimmunity and Immunetolerance. Egyptian Journal of Immunology, 13, 99-104.

[17] Trajkovski, V., Petlichkovski, A., Efinska-Mladenovska, O., Trajkov, D., Arsov, T., Strzova, A., et al. (2008) Higher Plasma Concentrations of Food Specific Antibodies in Persons with Autistic Disorder in Comparison to Their Siblings. Focus on Autism and Other Developmental Disabilities, 23, 176-186. http://dx.doi.org/10.1177/1088357608320413

[18] Vojdani, A., O’Bryan, T., Green, J.A., McCandless, J., Woeller, K.N., Vojdani, A.A., et al. (2004) Immune Response to Dietary Proteins, Gliadin and Cerebellar Peptides in Children with Autism. Nutritional Neuroscience, 7, 151-161.

[19] Lau, F.M., Green, R.H.P., Taylor, A.K., Helberg, D., Ajamian, M., Tan, C.Z., et al. (2013) Markers of Celiac Disease and Gluten Sensitivity in Children with Autism. PLoS One, 8, Article ID: e66158.

[20] Panksepp, J., Normansell, L., Sivily, S., Rossi, J. and Zolovick, A.J. (1978) Casomorphins Reduce Separation Distress in Chickens. Peptides, 5, 829-831. http://dx.doi.org/10.1016/0196-9781(84)90030-5

[21] Svedberg, J., De Haas, J., Leimanstoll, G., Paul, F. and Teschemacher, H. (1985) Demonstration of Beta-Casomorphin Immunoreactive Materials in Vitro Digests of Bovine Milk and in Small Intestinal Contents after Bovine Milk Ingestion in Adult Humans. Peptides, 6, 825-831. http://dx.doi.org/10.1016/0196-9781(85)90308-0

[22] Chabance, B., Marteau, P., Rambaud, J.C., Migliore-Samour, D., Boynard, M., Perrotin, P., et al. (1998) Casein Peptides Release and Passage to the Blood in Humans during Digestion of Milk and Yogurt. Biochimie, 80, 155-165. http://dx.doi.org/10.1016/S0300-9084(98)80022-9

[23] Gardner, M.L.G. (1994) Absorption of Intact Proteins and Peptides. In: Johnson, L.R., Ed., Physiology of the Gastrointestinal Tract, Raven Press, New York, 1795-1820.

[24] Mahe, S., Tome, D., Demontier, A.M. and Desjeux, J.F. (1989) Absorption of Intact Morphiceptin by Diisopropylflurophosphate-Treated Rabbit Ileum. Peptides, 10, 45-52. http://dx.doi.org/10.1016/0196-9781(89)90074-0 
[25] Bouras, M., Huneau, J.F. and Tome, D. (1996) The inhibition of Intestinal Dipeptidylaminopeptidase-IV Promotes the Absorption of Enterostatin and Des-Arginine-Enterostatin across Rat Jejunum in vitro. Life Sciences, 59, 2147-355. http://dx.doi.org/10.1016/S0024-3205(96)00571-1

[26] Kastin, A.J., Nissen, C., Schally. A.V. and Coy, D.H. (1979) Additional Evidence That Small Amounts of a Peptide Can Cross the Blood Brain Barrier. Pharmacology Biochemistry and Behavior, 14, 717-719. http://dx.doi.org/10.1016/0091-3057(79)90269-7

[27] Ermisch, A., Brust, P., Kretzchmar, R. and Buhle, H.J. (1983) On the Blood-Brain Barrier to Peptides (3H) Beta-Casomorphin-5 Uptake Byeighteen Brain Regions in Vivo. Journal of Neurochemistry, 41, 1229-1233. http://dx.doi.org/10.1111/j.1471-4159.1983.tb00816.x

[28] Husby, S., Jensenius, J.C. and Cant, A.J. (1984) Passage of Undegraded Dietary Antigen into the Blood of Healthy Adults. Scandinavian Journal of Immunology, 22, 83-92. http://dx.doi.org/10.1111/j.1365-3083.1985.tb01862.x

[29] Seifert, J., Ganser, R. and Brebdel, W. (1979) Die resorption eines proteolytischesproteins pflanzlichen ursprunge aus dem magen-darmtraktin das blut und in die lymphe von erwachsenen ratten. Z Gastroenterol., 17, 1-8.

[30] Axelsson, I., Jacobsson, I., Lindberg, T. and Benediktsson, B. (1986) Bovine Lactoglobulin in Human Milk. Acta Paediatrica. Scand., 75, 702-707. http://dx.doi.org/10.1111/j.1651-2227.1986.tb10277.x

[31] Troncone, F., Scarcello, A., Donatiello, A., Cannataro, P., Tabusco, A. and Auricchio, S. (1987) Passage of Gliadin into Human Breast Milk. Acta paediatrica Scandinavica, 76, 453-456. http://dx.doi.org/10.1111/j.1651-2227.1987.tb10498.x

[32] Langer, S.Z. (1997) 25 Years since the Discovery of Presynaptic Receptors: Present Knowledge and Future Perspectives. Trends in Pharmacological Sciences, 18, 95-99. http://dx.doi.org/10.1016/S0165-6147(96)01034-6

[33] Hadjivassiliou, M., Boscolo, S., Davies-Jones, G.A.B., Grünewald, R.A., Not, T., Sanders, D.S., et al. (2002) The Humoral Response in the Pathogenesis of Gluten Ataxia. Neurology, 58, 1221-1226. http://dx.doi.org/10.1212/WNL.58.8.1221

[34] Horvath, K., Papadimitriou, J.C., Rabaztyn, A., Drachenberg, C. and Tildon, I.T. (1999) Gastrointestinal Abnormalities in Children with Autistic Disorder. Journal of Pediatrics, 135, 559-563. http://dx.doi.org/10.1016/S0022-3476(99)70052-1

[35] Torrente, F., Ashwood, P., Day, R., Marchado, N., Furlano, R.I., Anthony, A., et al. (2002) Small Intestinal Enteropathy with Epithelial IgG and Complement Deposition in Children with Regressive Autism. Molecular Psychiatry, 7, 375-382. http://dx.doi.org/10.1038/sj.mp.4001077

[36] Wakefield, A.J., Anthony, A., Murch, S.H., Thomson, M., Montgomery, S.M., Davies, S., et al. (2000) Enterocolitis in Children with Developmental Disorders. The American Journal of Gastroenterology, 95, 2285-2295. http://dx.doi.org/10.1111/j.1572-0241.2000.03248.x

[37] Jyonouchi, H., Sun, S. and Itokazu, N. (2002) Innate Immunity Associated with Inflammatory Responses and Cytokine Production against Common Dietary Proteins in Patients with Autism Spectrum Disorder. Neuropsychobiology, 46, 76-84. http://dx.doi.org/10.1159/000065416

[38] Heyman, M. and Desjeux, J.F. (2000) Cytokine-Induced Alteration of Epithelial Barrier to Food Antigens in Disease. Annals of the New York Academy of Sciences, 915, 304-311. http://dx.doi.org/10.1111/j.1749-6632.2000.tb05258.x

[39] D’Eufemia, P., Celli, M., Finnochiaro, R., Pacifico, L., Viozzi, I., Zaccagnini, M., et al. (1996) Abnormal Intestinal Permeability in Children with Autism. Acta Paediatrica, 85, 1076-1079. http://dx.doi.org/10.1111/j.1651-2227.1996.tb14220.x

[40] de Magistris, L., Familian, V., Pascotto, A., Sapone, A., From, A., Iardino, P., et al. (2010) Alterations of the Intestinal Barrier in Patients with Autism Spectrum Disorders and Their First-Degree Relatives. Journal of Pediatric Gastroenterology and Nutrition, 51, 418-424. http://dx.doi.org/10.1097/MPG.0b013e3181dcc4a5

[41] Knivsberg, A.-M., Wiig, K., Lind, G., Nødland, M. and Reichelt, K.L. (1990) Dietary Intervention in Autistic Syndromes. Brain Dysfunction, 3, 315-327.

[42] Lucarelli, S., Frediani, T., Zingoni, A.M., Ferruzzi, F., Giardini, O., Quintieri, F., et al. (1995) Food Allergy and Infantile Autism. Panminerva Medica, 37, 137-141.

[43] Whiteley, P., Rodgers, J., Savery, D. and Shattock, P. (1999) A Gluten-Free Diet as an Intervention for Autism and Associated Spectrum Disorders: Preliminary Findings. Autism, 3, 45-65. http://dx.doi.org/10.1177/1362361399003001005

[44] Klaveness, J. and Bigam, J. (2002) The GFCF Kids Diet Survey. The Autism Research Unit, University of Sunderland, 77-84.

[45] Rimland, B. (2003) Parent Rating of Behavioral Effects of Biomedical Interventions. ARI Publ. 34.

[46] Kniker, W.T., Andrews, A., Hundley, A. and Garver, C. (2001) The Possible Role of Intolerance to Milk/Dairy and 
Wheat/Gluten Foods in Older Children and Adults with Autism Spectrum Disorder. The Autism Research Unit, University of Sunderland, 183-191.

[47] Brudnak, M.A., Rimland, B., Kerry, R.E., Dailey, M., Taylor, R., Stayton, B., et al. (2002) Enzyme-Based Therapy for Autism Spectrum Disorders-Is It Worth another Look? Medical Hypotheses, 58, 422-428. http://dx.doi.org/10.1054/mehy.2001.1513

[48] Whiteley, P., Haracopos, D., Knivsberg, A.-M., Reichelt, K., Parlar, S., Jacobsen, J., et al. (2010) The Scan Brit Randomised, Controlled, Single-Blind Study of a Gluten- and Casein-Free Dietary Intervention for Children with Autism Spectrum Disorders. Nutritional Neuroscience, 13, 87-100.

[49] Pennesi, C.M. and Klein, L.C. (2012) Effectiveness of the Gluten Free, Casein Free Diet for Children Diagnosed with Autism Spectrum Disorder. Based on Parental Report. Nutritional Neuroscience, 15, 85-91.

[50] Knivsberg, A.-M., Reichelt, K.L., Høien, T. and Nødland, M. (2002) A Randomized, Controlled Study of Dietary Intervention in Autistic Syndromes. Nutritional Neuroscience 5, 251-261.

[51] Knivsberg, A.-M., Reichelt, K.L., Nødland, M. and Høien, T. (1995) Autistic Syndromes and Diet: A Follow-Up Study. Scandinavian Journal of Educational Research, 39, 223-236. http://dx.doi.org/10.1080/0031383950390304

[52] Garrecht, M. and Austin, D.W. (2011) The Plausibility of a Role for Mercury in the Etiology of Autism: A Cellular Perspective. Toxicological \& Environmental Chemistry, 93, 1251-1273. http://dx.doi.org/10.1080/02772248.2011.580588

[53] Nataf, R., Skorupka, C., Amet, L., Lam, A., Springbett, A. and Lathe, R. (2006) Porphyrinuria in Childhood Autistic Disorder: Implications for Environmental Toxicity. Toxicology and Applied Pharmacology, 214, 99-108. http://dx.doi.org/10.1016/j.taap.2006.04.008

[54] Yong, L.J., Pitkow, L.J. and Ferguson, I.N. (2001) The Neuropathogenesis of Mercury Toxicity. Molecular Psychiatry, 7, 540-541.

[55] Reichelt, K.L., Tveiten, D., Knivasberg, A.-M. and Brønstad, G. (2012) Peptides Role in Autism with Emphasis on Exorphins. Microbial Ecology in Health and Disease, 23, 18958. http://dx.doi.org/10.3402/mehd.v23i0.18958 
Scientific Research Publishing (SCIRP) is one of the largest Open Access journal publishers. It is currently publishing more than 200 open access, online, peer-reviewed journals covering a wide range of academic disciplines. SCIRP serves the worldwide academic communities and contributes to the progress and application of science with its publication.

Other selected journals from SCIRP are listed as below. Submit your manuscript to us via either submit@scirp.org or Online Submission Portal.
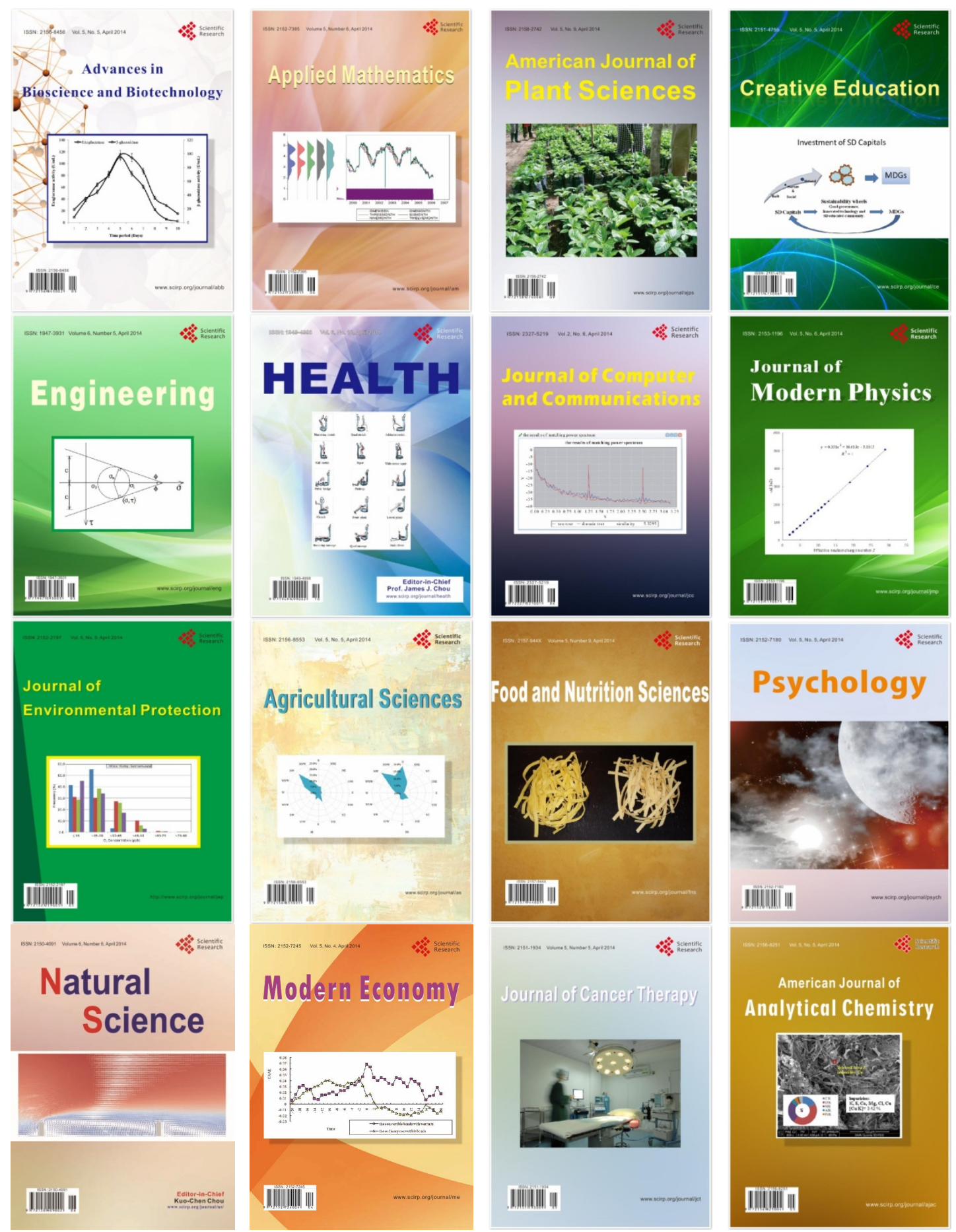